\title{
THE CADETS AND THE REASONS FOR THEIR DROP-OUT OF THE NATIONAL MILITARY UNIVERSITY
}

\author{
Venelin Terziev ${ }^{1}$, Margarita Bogdanova ${ }^{2}$, Dimitar Kanev ${ }^{3}$, Marin Georgiev ${ }^{4}$ \\ ${ }^{1}$ Full Member of the Russian Academy of Natural History, Professor, Eng., D.Sc. (National \\ Security), D.Sc. (Economics), D.Sc. (Social Activities), Ph.D., Russian Academy of Natural History, \\ Moscow, Russia, Vasil Levski National Military University, Veliko Tarnovo, Bulgaria University of \\ Rousse, Rousse, Bulgaria, terziev@skmat.com \\ ${ }^{2}$ Professor, Ph.D., Tsenov Academy of Economics - Svishtov, Bulgaria, \\ m.bogdanova@uni-svishtov.bg \\ ${ }^{3}$ Professor, D.Sc. (Ec.), Ph.D.Nikola Vaptsarov Naval Academy, Varna, Bulgaria, \\ kanev@dkanev.com \\ ${ }^{4}$ Ph.D., National Military University, Veliko Tarnovo, Bulgaria, clementon@abv.bg
}

\begin{abstract}
The goal of the present study is to reveal the essence of the reasons that lead to cadets' drop out of the AllArmy Faculty of National Military University and to propose actions for their impact reduction.

In order to achieve one of the sub-goals of the present study, namely to uncover the essence of the reasons that lead to drop off of cadets from the All-Army Faculty, it is necessary to take into consideration the trainees' opinion, to outline the achievements and the disadvantages of the overall organization of living and studying in the National Military University from their point of view.
\end{abstract}

Keywords: drop-out, cadets, education, National Military University.

\section{INTRODUCTION}

At the moment, in the higher military schools system of the Ministry of Defence of the Republic of Bulgaria more and more attention is paid to the problem for ensuring the process of preparation of qualified cadres, which process is directed mainly to the professional and individual development of the future officers. We should hint that the problem with the personality of the future officer occupies one of the leading places in the fundamental as well as in practical psychology. This is due to the necessity of strengthening the human factor at first, in favour of successful solving of the tasks before the military schools for preparation of highly qualified officers cadres. Second, it is very important a decisive turn to be made from mass, general approach towards the education and upbringing of cadets towards individual one for developing the creative skills of the cadets.

The cadet is included in a new for him type of leading activity - educational-professional, which proper organization defines in many aspects his forming as subject of consecutive military-professional activity as well as his attitude towards work. The connection between education and cadets' development is one of the basic problems of pedagogic psychology. While reviewing it, it is very significant that the development itself 
is a complex involutionary-evolutionary movement ahead, during which intellectual and behavioral changes occur in the cadet.

In order to eliminate the behavioral imbalances connected with the age, the commanders and teachers should competently conduct psycho-correctional work. The main efforts should be directed towards general propagation of educational process as a leading activity. Each teacher should prove the significance of his subjects and the studying of particular topic with motives, to put forward the question why and what for this knowledge is needed in their future professional activities, and to answer that question emphasizing on something significant (important, good) and something insignificant but with appropriate arguments and to make reference to competent sources (Terziev, Nichev, 2017).

Commanders and teachers often have increased requirements towards the cadets (especially in the first years of the education), they forget that the process of adapting to new conditions has not finished yet: the old stereotypes are preserved and the level of development, as a rule, does not meet the requirements of the military system. Here, it is important to be understood and to explain the cadets that not knowing something is not so bad, the most important is for them to strive towards knowledge and improvement of professional skills. An important direction at the forming the officer's personality is educating the cadets in striving for moral purity, high ideals and feelings. This is especially up-to-date in the circumstances, when the society is living through dangerous trends of general cultural crisis, which manifests in the rise of anti-human, antihumanistic values and ideals. In order to get over them, it is necessary precisely to define and correct the actions of all subjects in the educational and educative process. It turns out there are a lot of „sculptures” (commanders, teachers), and there is just one "sculpture" - the cadet. This is a problem of unified pedagogic activity. It is necessary to establish professional and moral culture, to develop the necessity of receiving significant information, acquiring range of professional knowledge, skills and capabilities. Improving cultural and educational level reduces the cadets' dependency on random and purposeful factors (environment, external circle, media, etc.).

Special attention should be paid to studying popular opinion, which would serve for prognosticating cadets' behaviour. Here significant role is given to sociological analysis, which allows the commanders and teachers to find the social differences of young people, to define their interests, possible desired and undesired counter reactions; elaborating methodology for information analysis; to formulate recommendations for selection and adaption of goals, methods and tools for influencing (Terziev, Nichev, 2017; Terziev, 2017a).

\section{THE EDUCATION OF CADETS AND PSYCHOLOGICAL ASPECT OF THE REASONS FOR THEIR DROP-OUT OF THE NATIONAL MILITARY UNIVERSITY}

The goal of the present study is to uncover the essence of reasons that lead to cadets' drop off from the AllArmy Faculty of Vasil Levski National Military University and to suggest actions for their influence reduction (Terziev, Banabakova, Georgiev, 2017b).

The reasons for discharging cadets are indicated in the Regulation for the Organization and Activity of Vasil Levski National Military University, published in State Gazette issue 83 of September 19th 2003, amended SG issue 56 of July 8th 2005, amended SG issue109 of December 23rd 2008.

Cadets are discharged from the university before the end of the term of education for the following reasons:

- For convicting of an intentional crime of general nature;

- For poor results;

- According to disciplinary order;

- At own free will;

- At occurring inability for military service, found by the competent healthcare bodies;

- At suspension of the allowance for access to classified information.

Here the cases, where single cadets are deprived of the physical ability to study in Vasil Levski National Military i.e. death, should also be added.

Cadets are discharged according disciplinary order when giving untrue data, on which grounds are accepted in the university and on systematic negligence of obligations on the curriculum or the university's regulations.

The obligations on the curriculum are considered systematically neglected when being absent more than 50 percent of the studying time of a semester, not certified semester or poor results. Semester is considered not certified when 3 or more studied subjects are not certified by the teachers because of unfulfilled study tasks. 
Obligations on the curriculum are considered unfulfilled because of poor results at three poor marks, given at regular semester exam session; two poor marks, given at correctional semester exam session; poor mark, given at liquidation exam session.

Systematic breaking the university regulations presents at the occurrence of three or more violations of obligations established with the university's regulations, committed by the trainees at the time of training.

According to the Law of Defence and Armed Forces (LDAF) of the Republic of Bulgaria, disciplinary punishment discharge, from the point of view of the fact that cadets are military men with special status, is obligatory imposed in the following cases:

- Conviction for intentional crime of general nature or deprivation of the right to occupy a state position or to exercise the profession or activity;

- Violation of the prohibitions to be members of political parties, movements and coalitions with political goals and to undertake actions within their service, with which they violate their political neutrality and to go on strike and to syndical activities;

- Failure to file a declaration according to the rules of LDAF;

- Systematic violation of rules for protection of the classified information, lead to unregulated access within the meaning of the Law for the Protection of the Classified Information;

- Failure to appear at work without reasonable causes in two working days in succession;

- Misuse of the official status;

- Destruction of property - state ownership, loss of materials, raw materials, energy and other means, when substantial damage has been caused to the state;

- Appearing of the military serviceman in a condition, which does not let him implement his official duties, because of using alcohol or misuse of narcotic substances;

- When because of guilty behaviour of the military serviceman there is a case of death or physical injury of his submitted military serviceman.

The analysis of the regulatory framework of the Republic of Bulgaria and of Vasil Levski National Military shows that the cases of discharging cadets from the university before the end of the term of education listed above could be classified in the following groups (Terziev, 2017a; Terziev, Banabakova, Georgiev, 2017b; Terziev, Nichev. Bogdanov, 2017c; Terziev, Nichev, 2017d):

- After disciplinary order, including at conviction for intentional crime of general nature and at deprivation of the allowance for access to classified information;

- Because of poor results;

- After own free will;

- Because of health reasons;

- Because of death.

The study covered the cadets from military specialties "Organization and Management of the Tactic Subdivisions of Land Forces" with specialization "motorized and tank troops", "signaling intelligence and ewar", "troops for nuclear, chemical and biologic protection and ecology", "engineer troops", "intelligence"; "Organization and Management of the Tactic Subdivisions for Logistic Provision" with specialization "troops in the rear and fuel-lubricant materials (FLM)" and "moving and transport" and "tank troops - technical and automobile troops" and "Organization and Management of military organizations at tactic level" with specialization "motorized and tank troops", "signaling intelligence and e-war", "troops for nuclear, chemical and biologic protection and ecology", "engineer troops", "intelligence", "material means, moving and transport", "tank and automobile equipment" in the period 2008 - 2017. Summarized data about the studied group are shown in Table 1.

The results show that the average percentage of discharged cadets out of the total number of trainees in certain military specialization for the period $2008-2017$ is $3,11 \%$. The highest percentages of dropped off are in military specializations „intelligence" and "material means, moving and transport" respectively $4,87 \%$ and $4,20 \%$, and the lowest one is in specialization "troops for nuclear, chemical and biologic protection and ecology". The percentage of discharged cadets out of the total number of trainees in certain military specialization for the period $2008-2017$ is shown on Figure 1. 
Table 1. Summarized data about the studied group.

\begin{tabular}{|c|c|c|c|c|c|c|}
\hline \multirow[b]{2}{*}{ Military Specialization } & \multirow[b]{2}{*}{$\begin{array}{l}\text { Number } \\
\text { of } \\
\text { trainees }\end{array}$} & \multicolumn{5}{|c|}{ Reasons for dropping off } \\
\hline & & 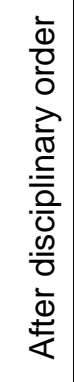 & 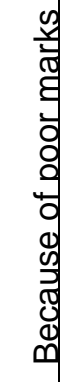 & 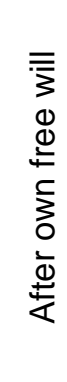 & 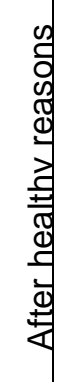 & 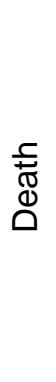 \\
\hline Motorized and tank troops & 514 & - & - & 12 & - & 2 \\
\hline Intelligence & 267 & 1 & 4 & 7 & 1 & - \\
\hline Signal intelligence and e-war & 127 & - & - & 3 & - & - \\
\hline Engineer troops & 247 & - & 1 & 3 & 1 & - \\
\hline $\begin{array}{l}\text { Troops for nuclear, chemical } \\
\text { and biologic protection and } \\
\text { ecology }\end{array}$ & 178 & 1 & - & 1 & - & - \\
\hline $\begin{array}{c}\text { Material means, moving and } \\
\text { transport }\end{array}$ & 429 & - & - & 16 & 2 & - \\
\hline $\begin{array}{l}\text { Tank and automobile } \\
\text { equipment }\end{array}$ & 363 & - & 3 & 6 & 2 & - \\
\hline
\end{tabular}

\section{Military specializations}

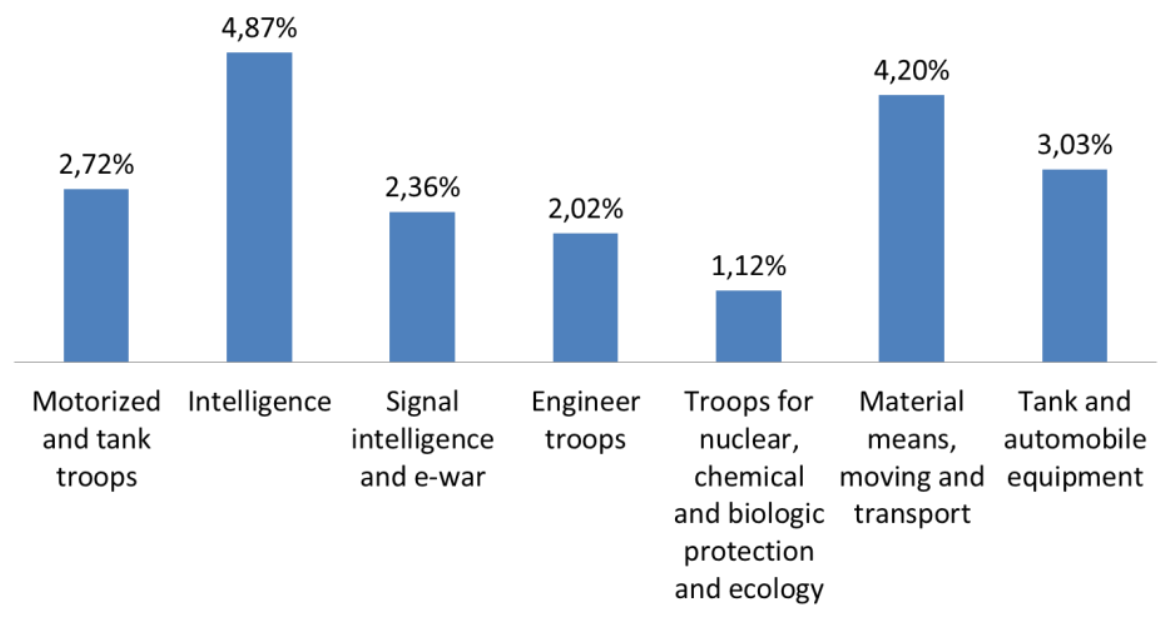

Figure 1. Discharged cadets out of the total number of trainees in certain military specialization.

The analysis of data shows that $72,73 \%$ of the discharged cadets are discharged after their free will, and the least are the ones that have dropped off because of death and after disciplinary order. Figure 2 shows the distribution of discharged cadets by groups of reasons for discharging cadets form the university before the term of education's end out of the total number of discharged cadets for the period $2008-2017$.

According to the analysis's results it can be found that the discharged cadets after their free will are almost 
three fourths of the total volume of discharged cadets and this imposes detailed review of this group of reasons. The cadets discharged after their free will by military specializations are shown of Figure 3 , and Figure 4 shows the dynamics of discharging cadets after their free will for the period $2008-2017$.

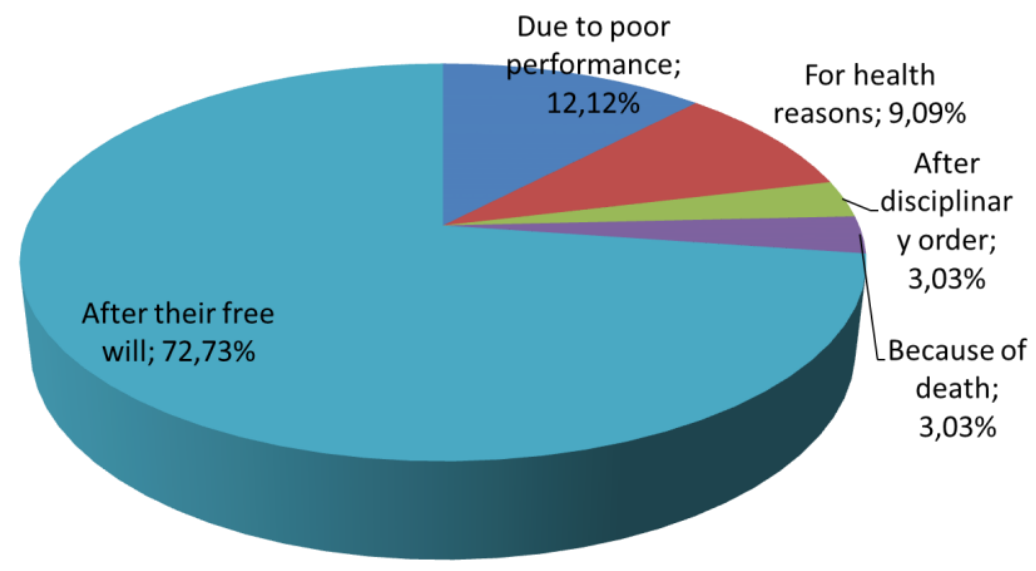

Figure 2. Discharged cadets according to the reasons for discharging from National Military University.

\section{Military specializations}

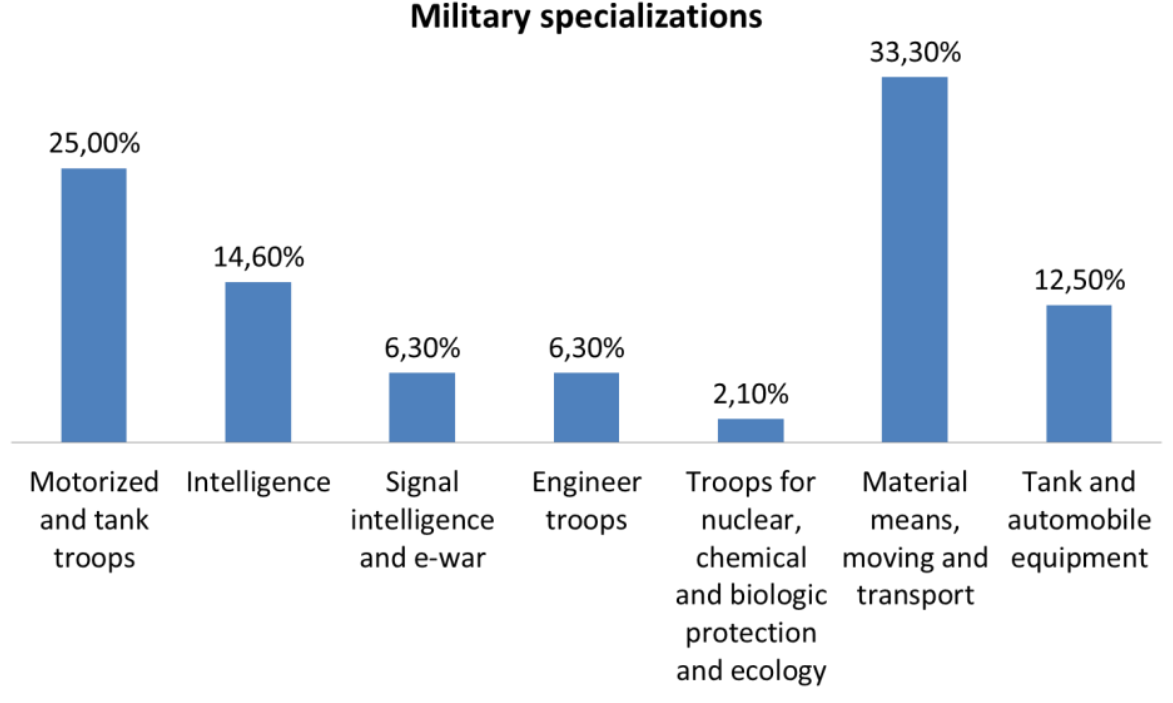

Figure 3. Discharged cadets after their free will by military specializations.

\section{Years}

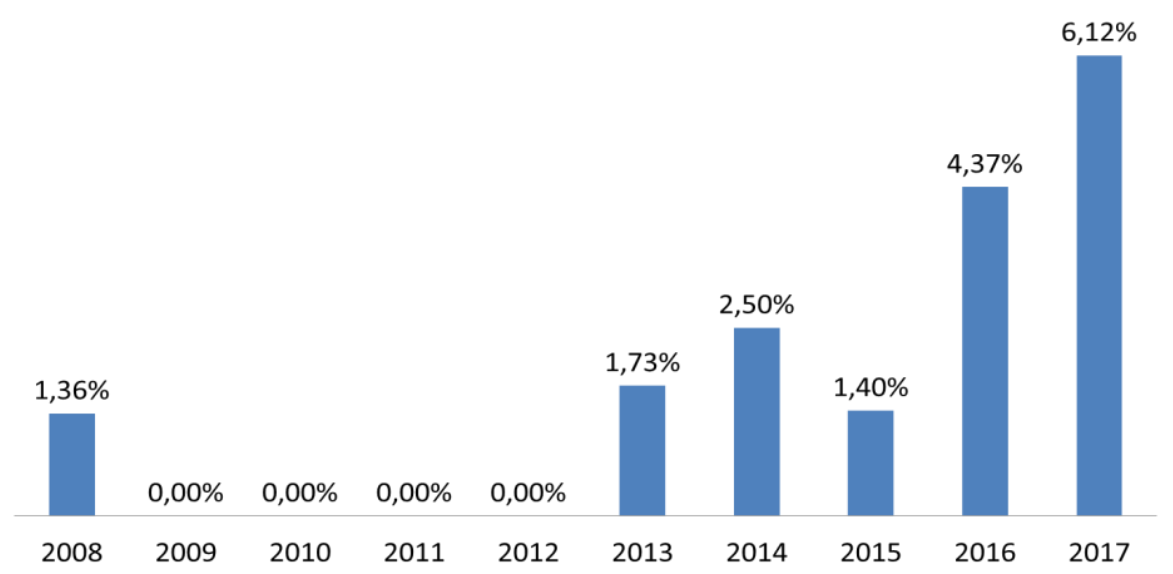

Figure 4. Dynamics of discharging cadets after their free will for the period $2008-2017$. 
The analysis of data shows that the military specializations from where most of the cadets drop off are material means, moving and transport and motorized and tank troops respectively $33,3 \%$ and $25 \%$. Significant exceeding of the ones, who wish to leave the military university over the average levels is observed in the period 2016 - 2017, and in the period 2010-2012 there is no discharged cadet after his free will. Because of that reason, the period $2016-2017$ would be analyzed in details.

The second ranking significant reason for dropping off of cadets is poor marks $(12,12 \%)$. The cadets discharged because of poor marks by military specializations are shown on figure 5 , and figure 6 shows the dynamics of discharging cadets because of poor marks for the period $2008-2017$. It is visible from the presented data that the quantity of discharged cadets trained with additional civil engineer specialty is equal to the dropped off cadets trained with additional civil non-engineer specialty.

\section{Military specialitations}

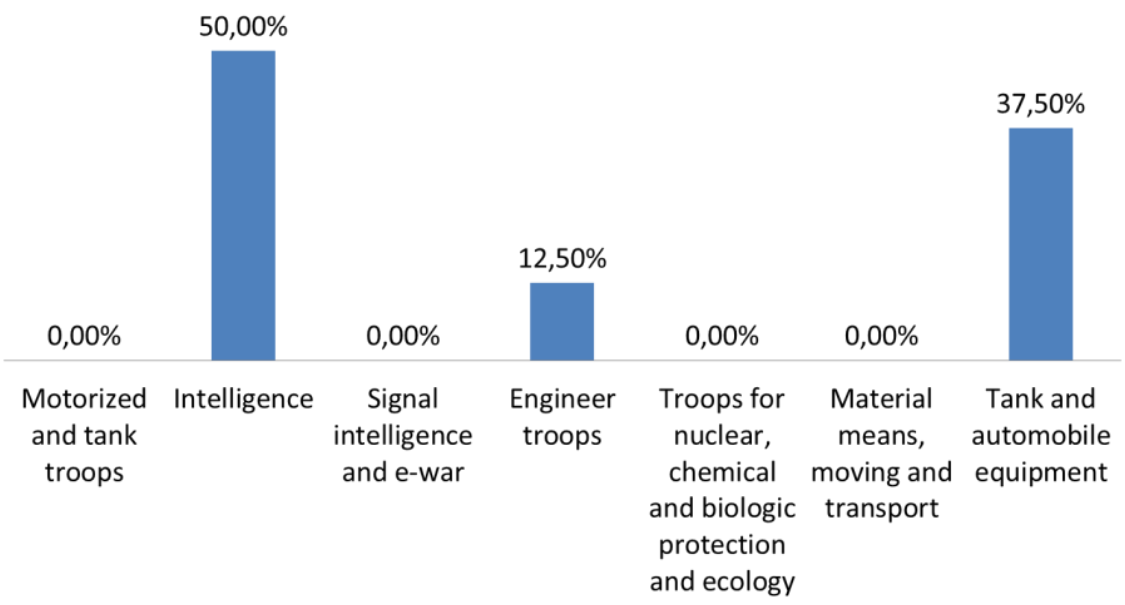

Figure 5. Discharged cadets because of poor marks by military specializations

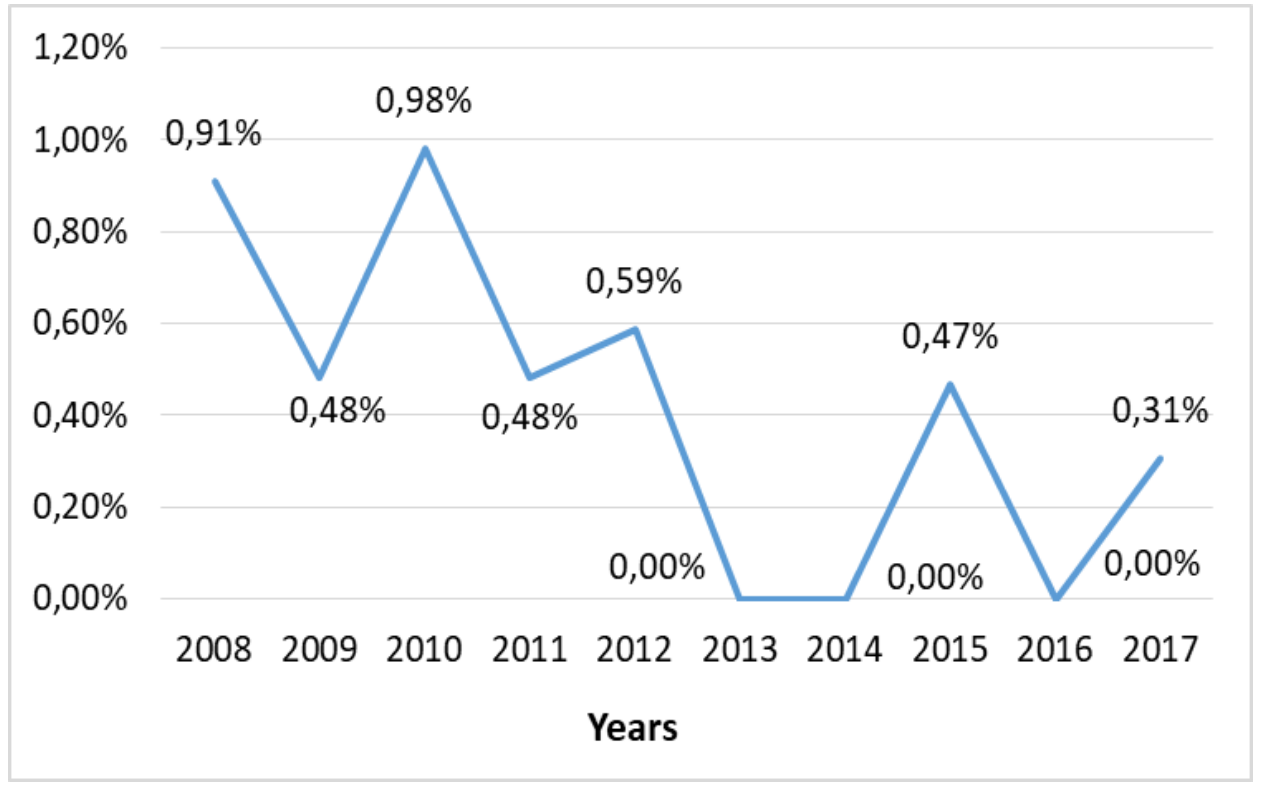

Figure 6. Dynamics of discharging cadets because of poor marks.

The actually trained cadets during the studied period are of interest for the present study. It is visible that during the reviewed period there are two trends visibly distinguished - in the period 2008-2014, a trend of gradual reduction of the cadets trained in All-Army Faculty is observed, and during the second period, 20142017, the number of cadets trained in the All-Army Faculty sharply increases more than twice (204\%). Both trends are illustrated on Figure 7. 


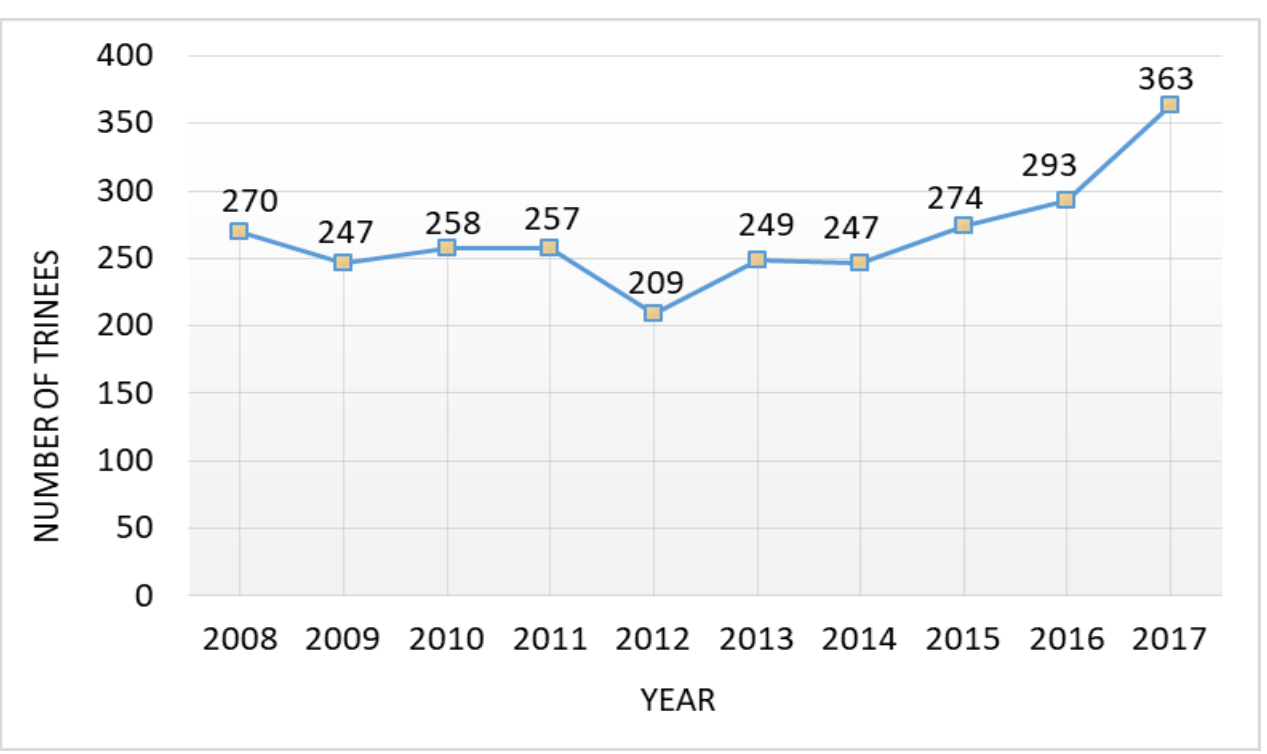

Figure 7. Actually trained cadets in the All-Army Faculty in the period 2008-2017.

In order to achieve one of the sub-goals of the present study, namely to uncover the essence of the reasons that lead to drop off of cadets from the All-Army Faculty, it is necessary to take into consideration the trainees' opinion, to outline the achievements and the disadvantages of the overall organization of living and studying in the National Military University from their point of view.

Tracing the dynamics of development of the studied cadets' opinion is achieved Tracking the dynamics of development of the surveyed cadets' opinion is achieved through the adopted by the Vasil Levski National Military University Academic Board Methods for considering the trainees' opinion on the studying process and on the administrative service in National Military University. It regulates the goal, subject, object, methods and organization of surveying and the way of reporting the trainees' opinion (Terziev, Nichev, 2017e; Nichev, 2017f; Nichev, 2017g; Nichev, 2017h; Georgiev, 2019; Georgiev, 2019a).

The method, through which the opinion of the National Military University's trainees is studied, is a questionnaire card, specified for each group of studied people.

\section{CONCLUSION}

The psychologists from section „Military Psychology” process the data and elaborate summarized report with the results from the questionnaire survey for each category of trainees and then present it to the Head of the University. On the grounds of the received results' analysis, "Training and Accreditation Department” of the NMU elaborates plan for improving training process's and way of living's quality and submits it to the Academic Senate for adoption (Glushkov, Simeonov, Georgiev, 2018; Glushkov, Simeonov, 2018a; Glushkov, Simeonov, 2018b).

The methods of evaluation of the education and specialty maintenance quality defines the goal, the criteria, indicators, order and sequence of conducting the evaluation of education and specialty maintenance quality. It aims collecting, summarizing and presenting information to the university's academic management (faculty), to the university's (faculty's) commission on the quality for improving the activities in all directions, which to improve the quality of education and scientific activity for achieving correspondence of the announced academic standards on the specialty. It has been adopted at a meeting of the Academic council in 2003, amended and supplemented at a meeting № 11/29.05.2007 of the Academic council and has never been applied (Angelov, 2015; Angelov, 2016-a)!

The methods of evaluation the quality of education and syllabus is developed as an element of the general evaluation (self-evaluation) of the quality management system in Vasil Levski National Military University and includes Syllabus Evaluation by basic criteria, their scope and contents, where the way of evaluation is indicated; Evaluation of the cadets' and students' preparation according to the users' opinion, which is formed on the grounds of a questionnaire with commanders, managers of companies and organizations, and chiefs at various levels during the trainees' probation period by indicators that form the criteria for the cadets and students; Evaluation of the teaching and mastering of the educational material - it is formed on the grounds of a questionnaire conducted among the trainees after indicators, grouped by the presented criteria, with separate training groups, classes or streams, not less than once a semester, after finishing certain topic, module or entire subject. 
The theoretic formulation and the empiric data of our work could be used by various experts (including teachers and psychologists) for diagnostics of personality and elaboration of recommendations for practice application of individual approach in the educational work regarding forming, development and correction of cadets' attributive style (Petrov, 2018c; Petrov, Georgiev, 2019b; Petrov, 2019c).

\section{REFERENCE LIST}

Terziev, V., Nichev, N. (2017). Analysis of the environment for military educational system functioning and its impact on the preparation of cadets for military professional activities in the republic of Bulgaria. // Proceedings of SOCIOINT 2017- 4th International Conference on Education, Social Sciences and Humanities 10-12 July 2017- Dubai, UAE, 2017, ISBN: 978-605-82433-1-6, pp.627-630.

Terziev, Venelin. (2017a). Comparative analysis of the formation of military professional skills in the cadets to be trained in logistics specializations. // 6th International Conference On Education (IC-ED-2017), University of Zagreb Zagreb - Croatia 29 June 2017 - 01 July 2017, Abstracts Book, 2017, p.89.

Terziev, V., Banabakova, V., Georgiev, M. (2017b). Comparative analysis of the formation of military professional skills in the cadets to be trained in logistics specializations in Bulgaria. // 4th Central \& Eastern European LUMEN International Scientific Conference on Education, Sport and Health, 29-30 September 2017, Chisinau, Republic of Moldova, 2017, ISBN: 978-973-166-479-8, pp.256-258.

Terziev, V., Nichev, N., Bogdanov, P. (2017c). Comparative analysis of the formation of military professional skills in the cadets to be trained in logistics specializations. // Proceedings of ADVED 2017-3rd International Conference on Advances in Education and Social Sciences 9-11 October 2017- Istanbul, Turkey, 2017, ISBN: 978-605-82433-0-9, pp.671-677.

Terziev, V., Nichev, N. (2017d). Developing the readiness for the organizational activity of the cadets. // CBU International Conference Book of Abstracts March 22-24, 2017, Prague, Czech Republic, Innovations in Science and Education, 2017, ISBN 978-80-88042-09-9, p.164.

Terziev, V., Nichev, N. (2017e). Developing the readiness for the organizational activity of the cadets. // CBU International Conference Proceedings 2017, March 22-24, Prague, Czech Republic, Innovations in Science and Education, 2017, SSN 1805-997X (Print), ISBN 978-80-88042-07-5 (Print edition), pp.915-919.

Nichev, Nikolay. (2017f). Research on the preparation and professional realisation of newly appointed logistics officers. // International Conference Knowledge-Based organization, Vol. XXIII, No 1, 2017, pp. 399-404, DOI: 10.1515/kbo-2017-0066.

Nichev, Nikolay. (2017g). Evaluation of the Nutrition of the Bulgarian Army Military Personnel During the Preparation for Participation in Expeditionary Operations. Buletin Ştiinţific, Volumul XXII Nr. 2 (44), 2017, Publisher "Nicolae Bălcescu” Land Forces Academy, Sibiu, Romania, pages: 97-103, ISSN 2247-8396.

Nichev, Nikolay. (2017h). Social Security as Part of the National Security System of Bulgaria. Security and Defence, No 1(14), 2017, Publishing House of War Studies University, Warsaw, Poland, pp. 3-20, ISSN 2300-8741.

Georgiev, Marin. (2019). Improvement of the forming of the military professional qualities during the educational process. // 21 st International scientific conference: The teacher of the future, Budva, Montenegro, (07-09.06.2019), Institute of knowledge management - Skopje, Macedonia, 31, 2019, 6, pp. 1945-1950, ISSN 1857-923X (for e-version), ISSN 2545 - 4439 (for printed version).

Georgiev, Marin. (2019a). Balansirana karta za otsenka kato instrument za usavarshenstvane na upravlenieto. Akademiya za inovatsii i ustoychivost, Plovdiv, 2019, 147 str., ISBN 978-619-7246-24-7 (Георгиев, Марин. Балансирана карта за оценка като инструмент за усъвършенстване на управлението. Академия за иновации и устойчивост, Пловдив, 2019, 147 стр., ISBN 978-6197246-24-7).

Glushkov, P., Simeonov, S., Georgiev, M. (2018). Method of determination of the diurnal energy consumption of the cadets from the Vasil Levski National Military University. // ADVED 2018- 4th International Conference on Advances in Education and Social Sciences Abstracts \& Proceedings, 1517 October 2018- Istanbul, Turkey, International Organization Center of Academic Research, 
www.ocerints.org, Istanbul, Turkey, 2018, pp. 88-92, ISBN: 978-605-82433-4-7.

Glushkov, P., Simeonov, S. (2018a). Study of the daily energy requirement of the cadets from Vasil Levski National Military University. // ADVED 2018- 4th International Conference on Advances in Education and Social Sciences Abstracts \& Proceedings, 15-17 October 2018- Istanbul, Turkey, International Organization Center of Academic Research, www.ocerints.org, Istanbul, Turkey, 2018, pp. 67-76, ISBN: 978-605-82433-4-7.

Glushkov, P., Simeonov, S. (2018b). Historical analysis of the daily energy requirements of the cadets in the Republic of Bulgaria. // ADVED 2018- 4th International Conference on Advances in Education and Social Sciences Abstracts \& Proceedings, 15-17 October 2018- Istanbul, Turkey, International Organization Center of Academic Research, www.ocerints.org, Istanbul, Turkey, 2018, pp. 77-87, ISBN: 978-605-82433-4-7.

Angelov, Ivaylo. (2015). Aviatsionnoto obrazovanie v usloviyata na globalizatsiya. // Sbornik dokladi ot Godishnata universitetska nauchna konferentsiya na NVU „Vasil Levski” 2015, tom 10, s. 99-108, Izdatelski kompleks na NVU „Vasil Levski”, Veliko Tarnovo, 2015, ISSN 1314-1937 (Ангелов, Ивайло. Авиационното образование в условията на глобализация. // Сборник доклади от Годишната университетска научна конференция на НВУ „Васил Левски” 2015, том 10, с. 99-108, Издателски комплекс на НВУ „Васил Левски”, Велико Търново, 2015, ISSN 1314-1937).

Angelov, Ivaylo. (2016). Politika na evropeyskiya sayuz za razvitieto na aviatsiyata i aviatsionnoto obrazovanie. // Yubileyna nauchna konferentsiya 14 - 15 april 2016 g., Fakultet "Aviatsionen” NVU „V. Levski”- Dolna Mitropoliya, s.301-311, 2016, ISBN 978-954-713-109-5 (Ангелов, Ивайло. Политика на европейския съюз за развитието на авиацията и авиационното образование. // Юбилейна научна конференция 14 - 15 април 2016 г., Факултет “Авиационен” НВУ „В. Левски”- Долна Митрополия, с.301-311, 2016, ISBN 978-954-713-109-5).

Angelov, Ivaylo. (2016a). Vissheto aviatsionno obrazovanie v drugi evropeyski darzhavi. // Sbornik ot dokladi na Yubileyna nauchna konferentsiya 14 - 15 april 2016 g., Fakultet” Aviatsionen” NVU „V. Levski”Dolna Mitropoliya, s.292-300, Elektronno izdanie, 2016, ISBN 978-954-713-109-5 (Ангелов, Ивайло. Висшето авиационно образование в други европейски държави. // Сборник от доклади на Юбилейна научна конфреренция 14 - 15 април 2016 г., Факултет” Авиационен” НВУ „В. Левски”Долна Митрополия, с.292-300, Електронно издание, 2016, ISBN 978-954-713-109-5).

Petrov, N. (2018c). Methopdology for asseing the quality of conducted training, Journal of Innovations and Sustainability, Vol. 4, No 3, 2018, p 27-37, ISSN 2367-8127 (CD-ROM), ISSN 2367-8151 (on-line).

Petrov, N., Georgiev, M. (2019b). Assessing of the military professional competencies. // Proceedings of SOCIOINT 2019- 6th International Conference on Education, Social Sciences and Humanities 24-26 June 2019- Istanbul, Turkey, International Organization Center of Academic Research, Istanbul, Turkey, 2019, pp. 462-472, ISBN: 978-605-82433-6-1.

Petrov, N, (2019c). Quality of conducted training system model. // Proceedings of SOCIOINT 2019-6th International Conference on Education, Social Sciences and Humanities 24-26 June 2019- Istanbul, Turkey, International Organization Center of Academic Research, Istanbul, Turkey, 2019, pp. 473-482, ISBN: 978-605-82433-6-1. 